Revista Eletrônica de Direito Processual - REDP.

Rio de Janeiro. Ano 13. Volume 20. Número 1. Janeiro a Abril de 2019

Periódico Quadrimestral da Pós-Graduação Stricto Sensu em Direito Processual da UERJ

Patrono: José Carlos Barbosa Moreira (in mem.). ISSN 1982-7636. pp. 513-531 www.redp.uerj.br

\title{
LIBERDADE DE IMPRENSA X PRESUNÇÃO DE INOCÊNCIA: DA NECESSÁRIA CONCORDÂNCIA PRÁTICA NO TRIBUNAL DO JÚRI ${ }^{1}$
}

\section{FREEDOM OF THE PRESS VS. PRESUMPTION OF INNOCENCE: THE ESSENTIAL BALANCE POINT IN THE JURY}

Túlio Felippe Xavier Januário Mestrando em Direito pela Universidade de Coimbra. Graduado pela Universidade Estadual Paulista "Júlio de Mesquita Filho" (UNESP). Pesquisador financiado pelo programa "ERASMUS+" na Georg-August-Universität Göttingen. Advogado. Pouso Alegre/MG. E-mail: tuliofxj@gmail.com

RESUMO: O presente trabalho tem como objetivo analisar o conflito existente entre a liberdade de imprensa, que é garantida, dentre outras, pelas Constituições vigentes no Brasil e em Portugal, e os direitos e garantias do Acusado, especialmente os da presunção de inocência, do devido processo legal e do juiz imparcial. Para tanto, foi feita a opção de restringir a análise ao âmbito do Tribunal do Júri, instituto no qual, conforme se observará, a problemática supracitada ganha maior evidência, diante das particularidades inerentes ao seu funcionamento e, mais especificamente, aos jurados e seus vereditos. Assim sendo, após breve introdução histórica, será feito um estudo sobre a atual conjuntura do tribunal popular nos ordenamentos jurídicos português e brasileiro e, apresentados os fundamentos da questão em comento, se buscará as possíveis alternativas para sua resolução.

PALAVRAS-CHAVE: Liberdade de imprensa; Presunção de inocência; Juiz imparcial; Tribunal do Júri; Fundamentação das decisões.

ABSTRACT: The aim of the present essay is to analyze the conflict between the freedom of the press, which is guaranteed by the Constitutions of Brazil and Portugal, and the defendant's rights, specially the due process of law and the impartial judge. Therefore, an

\footnotetext{
${ }^{1}$ Artigo recebido em 09/05/2018 e aprovado em 27/03/2019.
} 
Revista Eletrônica de Direito Processual - REDP.

Rio de Janeiro. Ano 13. Volume 20. Número 1. Janeiro a Abril de 2019

Periódico Quadrimestral da Pós-Graduação Stricto Sensu em Direito Processual da UERJ

Patrono: José Carlos Barbosa Moreira (in mem.). ISSN 1982-7636. pp. 513-531

www.redp.uerj.br

option to restrict the study to the Jury was made, because in this institute the problematic is potentialized, before its particularities and to the systematic of the members' decision. So, after a brief historical introduction, a study of the current situation of the Jury in Brazil and Portugal will be made, presenting its critical fundaments and the possible solutions to this issue.

KEYWORDS: Freedom of the press; presumption of innocence; impartial judge; jury; substantiation of the decisions.

SUMÁRIO: 1. Introdução. 2. Da íntima convicção e da consequente falta de fundamentação das decisões do conselho de sentença. 3. Da possível influência midiática na formação do convencimento dos jurados. 4. Do necessário ponto de concordância prática entre a presunção de inocência e a liberdade de imprensa. 5. Conclusão. 6. Referências.

\section{INTRODUÇÃO:}

Muito embora seja possível identificar alguns institutos anteriores inegavelmente semelhantes ao Tribunal do Júri, tais como os "centeni comites" ou "judices jurati”, em Roma, e o "heliastas", na Grécia antiga, foi, de fato, com a Magna Carta da Inglaterra, de 1215 , que o instituto foi concebido nas formas hoje conhecidas. ${ }^{2}$ Criado como forma de resistência aos poderes monárquicos, que se manifestavam muitas vezes através de decisões proferidas pelo judiciário que eram contrárias aos interesses da sociedade, o instituto era previsto pelo artigo 48 do referido diploma, que dispunha que ninguém poderia ser preso ou despojado de seus bens sem um julgamento de seus pares, sendo estes representados pelo chamado "Grand Jury" ou "Júri de Acusação", que por simbolizarem a vontade divina, deveriam julgar de acordo com o que sabiam, independentemente de quaisquer provas, com base no "vere dictum". 3

\footnotetext{
${ }^{2}$ Neste sentido: MACHADO, Antônio Alberto. Curso de processo penal. p. 274; RANGEL, Paulo. Direito processual penal. p. 529.

${ }^{3}$ RANGEL, Paulo. Op. Cit. p. 529-530.
} 
Revista Eletrônica de Direito Processual - REDP.

Rio de Janeiro. Ano 13. Volume 20. Número 1. Janeiro a Abril de 2019

Periódico Quadrimestral da Pós-Graduação Stricto Sensu em Direito Processual da UERJ

Patrono: José Carlos Barbosa Moreira (in mem.). ISSN 1982-7636. pp. 513-531

www.redp.uerj.br

No mesmo sentido, com a revolução de 1789, o procedimento do júri fora instituído

na França a fim de combater os métodos, ideias e abusos cometidos por magistrados durante o "ancién régime", que refletiam o mais puro autoritarismo característico da época.

Passou, então, a ser difundido em diferentes países europeus como um instituto de tutela das liberdades e da democracia, representado inegável freio às arbitrariedades judiciais e monárquicas. ${ }^{4}$

Em Portugal, o instituto passou a ser previsto pelo ordenamento jurídico com a Constituição de 1826, sendo já nesta época composto por juízes leigos e togados e sendo competente para o julgamento de ações cíveis e criminais. Após várias mudanças no seu procedimento, que foram sendo realizadas no decorrer do século, hoje é previsto pela Constituição da República Portuguesa em seu artigo $207^{5}$, sendo competente para o julgamento de crimes graves, exceto os de terrorismo e de criminalidade altamente organizada, nos termos do artigo 13 do Código de Processo Penal. ${ }^{6}{ }^{7}$

Para que haja, porém, a participação popular no julgamento dos crimes graves, deve haver requerimento por parte da acusação ou da defesa, ressalvados os casos de crimes de terrorismo ou criminalidade altamente organizada, nos quais a mesma é vedada em razão de sua natureza, uma vez que os jurados poderiam sofrer um elevado grau de ameaça ou intimidação. ${ }^{8} \mathrm{O}$ tribunal é formado por três juízes togados e quatro jurados efetivos, devendo todos decidir conjuntamente a questão da culpa e da sanção, mas somente os primeiros as questões prévias ou incidentais, relacionadas à admissão ou não de provas,

\footnotetext{
${ }^{4}$ NUCCI, Guilherme de Souza. Manual de processo penal e execução penal. p. 677.

5 "Art. 207. O júri, nos casos e com a composição que a lei fixar, intervém no julgamento dos crimes graves, salvo os de terrorismo e os de criminalidade altamente organizada, designadamente quando a acusação ou a defesa o requeiram.” PORTUGAL. Constituição da República Portuguesa. Disponível em:

$\langle$ http://www.parlamento.pt/Legislacao/Paginas/ConstituicaoRepublicaPortuguesa.aspx $>$. Acesso em $10 \mathrm{de}$ janeiro de 2017.

${ }^{6}$ JÓLLUSKIN, Glória. O tribunal do júri no ordenamento jurídico português: uma abordagem na perspectiva da psicologia. p. 118.

7 "Artigo $13^{\circ}$. Competência do tribunal do júri: 1 . Compete ao tribunal do júri julgar os processo que, tendo a intervenção do júri sido requerida pelo Ministério Público, pelo assistente, ou pelo arguido, respeitarem a crimes previstos no título III e no capítulo I do Título V do livro II do Código Penal e na Lei Penal Relativa às Violações do Direito Internacional Humanitário. 2. Compete ainda ao tribunal do júri julgar os processos que, não devendo ser julgados pelo tribunal singular e tendo a intervenção do júri sido requerida pelo Ministério Público, pelo assistente ou pelo arguido, respeitarem a crimes cuja pena máxima, abstractamente aplicável, for superior a 8 anos de prisão." PORTUGAL. Código de processo penal. Disponível em: < http://www.pgdlisboa.pt/leis/lei_mostra_articulado.php?nid=199\&tabela=leis $>$. Acesso em 10 de janeiro de 2017.

${ }^{8}$ MIRANDA, Jorge; MEDEIROS, Rui. Constituição portuguesa anotada - Tomo III. p. 94.
} 
Revista Eletrônica de Direito Processual - REDP.

Rio de Janeiro. Ano 13. Volume 20. Número 1. Janeiro a Abril de 2019

Periódico Quadrimestral da Pós-Graduação Stricto Sensu em Direito Processual da UERJ

Patrono: José Carlos Barbosa Moreira (in mem.). ISSN 1982-7636. pp. 513-531

www.redp.uerj.br

assim como relacionadas à audiência de julgamento, deliberação ou responsabilidade civil conexa. $^{9}$

No Brasil, por sua vez, o Tribunal do Júri foi instituído no ano de 1822 , sendo formado por 24 (vinte e quatro) cidadãos "bons, honrados, inteligentes e patriotas", competentes, inicialmente, para o julgamento de delitos de abuso da liberdade de imprensa e tendo suas decisões revisáveis somente pelo Príncipe Regente. ${ }^{10}{ }^{11}$ Tendo sido abolido apenas no período compreendido entre os anos de 1937 e 1946, atualmente o instituto é previsto pelo artigo $5^{\circ}$., inciso XXXVIII, da Constituição Federal ${ }^{12}$, sendo competente para o julgamento dos crimes dolosos contra a vida, consumados ou tentados. ${ }^{13}$ Incluem-se neste catálogo, o homicídio, o infanticídio, o auxílio ou instigação ao suicídio e o aborto. Importante destacar que esta competência é a chamada competência mínima do tribunal, de maneira com que poderá ser ampliada por lei ordinária. Além disso, o tribunal será competente para julgar os crimes conexos, sejam eles dolosos contra a vida ou não. ${ }^{14}$

No que se refere à sua composição, o Tribunal do Júri é composto por 01 (um) juiz togado, ou Juiz Presidente, ao qual caberá a direção e condução do procedimento, assim como a lavratura da sentença, e pelo Conselho de Sentença, formado por 07 (sete) jurados leigos, pessoas do povo, previamente sorteados, aos quais caberá responder aos quesitos referentes às questões de fato e de direito do caso concreto, de acordo com suas conclusões. $^{15}$

\footnotetext{
${ }^{9}$ Paulo Sérgio Pinto de Albuquerque entende que a referida solução é resultado de uma busca de equilíbrio entre a soberania da decisão popular e a busca do controle interno sobre a racionalidade da mesma. AlbuQUerQue, Paulo Sérgio Pinto de. Comentário do Código de Processo Penal: à luz da Constituição da República e da Convenção Européia dos Direitos do Homem. p. 75-77.

${ }^{10}$ NUCCI, Guilherme de Souza. Manual de processo penal e execução penal. p. 678.

${ }^{11}$ Boris Fausto explica que, com o avanço das tropas franceses rumo a Lisboa e com a consequente ida da família real portuguesa ao Brasil, no ano de 1807, todo um aparato burocrático fora levado à colônia, tais como ministros, conselheiros e juízes da corte suprema. Com o retorno do Príncipe Dom João VI à Portugal, segundo Paulo Rangel, no ano de 1821, e a posterior independência do Brasil, declarou-se que as leis portuguesas teriam aplicação no Brasil, desde que não conflitantes com sua soberania e com o novo regime, situação que perdurou até a Constituição de 1824. FAUSTO, Boris. História do Brasil. p. 121; RANGEL, Paulo. Direito processual penal. p. 530-532.

12 "Art. $5^{\circ}$. [...] XXXVIII - é reconhecida a instituição do júri, com a organização que lhe der a lei, assegurados: a) a plenitude de defesa; b) o sigilo das votações; c) a soberania dos vereditos; d) a competência para o julgamento dos crimes dolosos contra a vida. BRASIL. Constituição da República Federativa do Brasil de $1988 . \quad$ Disponível em: < http://www.planalto.gov.br/ccivil 03/constituicao/constituicaocompilado.htm >. Acesso em 11 de janeiro de 2017.

${ }^{13}$ NUCCI, Guilherme de Souza. Op. Cit. p. 678-679.

${ }^{14}$ DEZEM, Guilherme Madeira. Curso de processo penal. p. 754-755.

${ }^{15}$ OLIVEIRA, Eugênio Pacelli de. Curso de processo penal. p. 717.
} 


\section{DA ÍNTIMA CONVICÇÃO E DA CONSEQUENTE FALTA DE FUNDAMENTAÇÃO DAS DECISÕES DO CONSELHO DE SENTENÇA:}

Conforme destaca Antônio Alberto Machado, o tribunal do júri é um dos órgãos judiciais que mais despertam polêmicas no ordenamento jurídico brasileiro, possuindo ferrenhos defensores e adversários, sem, porém, que qualquer das partes tenha triunfo definitivo sobre a outra, uma vez que, se por um lado, não se vislumbra qualquer perspectiva de extinção da instituição num futuro próximo, por outro, os problemas que a acompanham desde sua criação ainda se encontram longe de acabar. ${ }^{16}$

Dentre seus principais pontos controversos, o da falta de motivação das decisões merece destaque. Conforme explica Eugênio Pacelli de Oliveira, o sistema de avaliação das provas adotado pelo sistema processual penal brasileiro é o do livre convencimento motivado, segundo o qual, muito embora não exija a adoção de critérios prévios de valoração, impõe a necessária fundamentação das decisões, devendo o magistrado declinar as razões que o levaram a optar ou não por determinada prova, nos termos do artigo 155 do Código de Processo Penal. ${ }^{17}{ }^{18}$ Assim, como leciona Guilherme de Souza Nucci, o método da persuasão racional, ou do livre convencimento motivado, não permite que o magistrado faça de suas vivências ou experiências pessoais acerca de algo, integrar o conjunto probatório, devendo o mesmo extrair suas conclusões do acervo produzido legalmente no processo, podendo, então, formar seu livre convencimento, devendo, porém, fundamentálo nos autos, persuadindo as partes e a comunidade em abstrato. ${ }^{19}$

Pelo contrário, os jurados valoram as provas e formam seu convencimento através do método da "íntima convicção", ou seja, não precisam expor os fatos e provas que os levaram a tal decisão, não necessitando, nem mesmo se aterem a verdade processualmente obtida sob contraditório. ${ }^{20}$ Conforme explica Guilherme Madeira Dezem, este sistema se baseia em uma ideia de certeza moral do magistrado, de maneira com que, por este

\footnotetext{
${ }^{16}$ MACHADO, Antônio Alberto. Curso de processo penal. p. 271.

${ }^{17}$ OLIVEIRA, Eugênio Pacelli de. Curso de processo penal. p. 340.

18 “Art. 155. O Juiz formará sua convicção pela livre apreciação da prova produzida em contraditório judicial, não podendo fundamentar sua decisão exclusivamente nos elementos informativos colhidos na investigação, ressalvadas as provas cautelares, não repetíveis e antecipadas." BRASIL. Decreto-Lei $n^{\circ}$. 3.689, de 3 de outubro de 1941: Código de Processo Penal. Disponível em: < http://www.planalto.gov.br/ccivil_03/decreto-lei/Del3689.htm >. Acesso em 11 de janeiro de 2017.

${ }^{19}$ NUCCI, Guilherme de Souza. Código de processo penal comentado. p.399-400.

${ }^{20}$ VIEIRA, Ana Lúcia Menezes. Processo penal e mídia. p. 246.
} 
Revista Eletrônica de Direito Processual - REDP.

Rio de Janeiro. Ano 13. Volume 20. Número 1. Janeiro a Abril de 2019

Periódico Quadrimestral da Pós-Graduação Stricto Sensu em Direito Processual da UERJ

Patrono: José Carlos Barbosa Moreira (in mem.). ISSN 1982-7636. pp. 513-531

www.redp.uerj.br

entendimento, não lhe seria exigível justificações a respeito de sua vontade e de suas razões, nos julgamentos. ${ }^{21}$

Um dos grandes riscos que se corre com a adoção do referido sistema pelo Tribunal do Júri é o de que os jurados não julguem somente de acordo com a verdade processualmente obtida, mas sim, se deixem influenciar por ideias preconcebidas, preconceitos e todas as espécies de intolerância que podem surgir não apenas no plenário, mas também a partir de informações obtidas por estes através de meios não necessariamente compromissados com a verdade. ${ }^{22}$ Neste sentido, entende Aury Lopes Jr. que a problemática em tela se agrava pelo fato de os jurados não estarem assegurados pelas mesmas garantias orgânicas que os membros da magistratura, os tornando mais influenciáveis por pressões exteriores, tais como políticas, econômicas e midiáticas. $^{23}$

\section{DA POSSÍVEL INFLUÊNCIA MIDIÁTICA NA FORMAÇÃO DO CONVENCIMENTO DOS JURADOS:}

Questão muito discutida pela doutrina e de difícil resolução, diz respeito à necessária compatibilização entre a liberdade de imprensa, inerente a qualquer democracia, e a manutenção do estado de inocência dos réus até que sentença condenatória transitada em julgado mude tal situação. No Brasil, tal temática tem ganhado bastante relevo, não apenas diante dos recentes casos de grande repercussão, aos quais a mídia, de forma geral, tem dedicado horas e páginas a fio, a fim de adiantar-se ao judiciário e chegar a conclusões antes mesmo do encerramento do inquérito policial. Os métodos e discursos adotados por parte da mesma, que ao fazerem investigações privadas e "espetacularizarem" a criminalidade, acabam desrespeitando garantias constitucionais dos acusados e difundindo uma cultura de medo e sensação de perigo constante, fazem com que a população se

\footnotetext{
${ }^{21}$ DEZEM, Guilherme Madeira. Curso de processo penal. p. 419.

22 OLIVEIRA, Eugênio Pacelli de. Curso de processo penal. p. 719.

${ }^{23}$ Diante deste quadro, e em virtude da não adoção de um sistema de exclusão física do inquérito policial dos autos do processo, que visaria impedir a contaminação do julgador pelos atos investigatórios praticados na fase inquisitória de investigação, abre-se mão da garantia de julgamento apenas com base em provas judicializadas, correndo-se o sério risco de decisões fundamentadas única e exclusivamente no inquérito policial ou, o que seria ainda mais grave, motivadas por elementos extraprocessuais e de caráter preconceituoso, tais como "cara", cor, opção sexual, religião, posição socioeconômica e aparência física. LOPES JR., Aury. Direito processual penal. p. 826-828.
} 
Revista Eletrônica de Direito Processual - REDP.

Rio de Janeiro. Ano 13. Volume 20. Número 1. Janeiro a Abril de 2019

Periódico Quadrimestral da Pós-Graduação Stricto Sensu em Direito Processual da UERJ

Patrono: José Carlos Barbosa Moreira (in mem.). ISSN 1982-7636. pp. 513-531

www.redp.uerj.br

inflame, acolha os discursos punitivistas por eles propagados e pressionem cada vez mais o judiciário por punições mais severas e constantes. ${ }^{24}{ }^{2} 25$

Especificamente no que se refere a casos de competência do Tribunal do Júri, o suposto assassinato de Isabela Nardoni, ocorrido em 29 de março de 2008, quando a menina de 06 (seis) anos teria sido arremessada da janela de um apartamento de São Paulo e os principais suspeitos seriam seu pai e sua madrasta, teve uma cobertura da imprensa marcada por vazamento de informações sigilosas, transmitidas ao grande público através de "furos" de reportagem e até alterações nas grades de programação das principais emissoras televisivas do país, para que pudessem ser feitas transmissões ao vivo da movimentação em torno do depoimento dos acusados, do trabalho dos peritos, das prisões temporárias e preventivas decretadas para ambos e, é claro, do julgamento. ${ }^{26}$

O resultado de toda esta exposição midiática, marcada por programas com constantes reconstituições do crime, intercaladas com fotos da criança quando ainda viva e sorridente, entrevistas com sua mãe ainda em fase de luto, participação de membros das maiores emissoras do país em manifestações públicas e missas e, é claro, declarações do promotor responsável pelo caso que, incansavelmente ia a público prometer que a justiça seria feita e o casal seria condenado, pôde ser observado na reação do público: semanas após o crime, pessoas de diversas partes do país acamparam na porta da casa dos acusados, fazendo coro e atirando pedras contra ambos. ${ }^{27}$ Alguns meses antes do julgamento, as linhas telefônicas do Fórum Regional de Santana ficaram congestionadas, em virtude do grande número de pessoas de diversas partes do Brasil, que desconhecendo o procedimento do júri, gostariam de saber como poderiam participar do mesmo para poder condenar o

\footnotetext{
${ }^{24}$ Neste sentido, Dalmo de Abreu Dallari entende que o comportamento da grande mídia acaba por transmitir ao público, através de seus programas pseudoinformativos, a sensação de que todos estão na iminência de ser vítima de alguma espécie de violência. DALLARI apud BECHARA, Ana Elisa Liberatore Silva. "Caso Isabella": violência, mídia e direito penal de emergência. p. 16.

${ }^{25}$ Exemplo deste discurso foi o proferido pela jornalista "Rachel Sheherazade, quando, em uma transmissão ao vivo de telejornal e após ridicularizar defensores de direitos humanos, lançou a campanha "adote um bandido", para aqueles que se indignaram com a atuação dos chamados "justiceiros do Bairro do Flamengo", jovens de classe média/alta do Rio de Janeiro que prenderam, amarraram e espancaram um jovem suspeito de furtos na região. Sob a justificativa de que o Estado seria falho e a polícia omissa, a jornalista sugere que seja feita justiça com as próprias mãos, justificada por uma suposta "legítima defesa da sociedade." GOMES, Luiz Flávio. Campanha da Sheherazade: adote um bandido!. p. 2.

${ }^{26}$ MORETZSOHN, Sylvia. "O crime que chocou o Brasil": mídia, justiça e opinião pública na primeira fase do caso Isabella Nardoni. p. 513.

${ }^{27}$ ARAÚJO, Marcelo Cunha de. A volta do discurso dos suplícios em um país ávido por vingança: os casos João Hélio e Isabella Nardoni. p. 193.
} 
Revista Eletrônica de Direito Processual - REDP.

Rio de Janeiro. Ano 13. Volume 20. Número 1. Janeiro a Abril de 2019

Periódico Quadrimestral da Pós-Graduação Stricto Sensu em Direito Processual da UERJ

Patrono: José Carlos Barbosa Moreira (in mem.). ISSN 1982-7636. pp. 513-531

www.redp.uerj.br

casal Nardoni. ${ }^{28}$ Sequer o advogado de defesa do casal, Roberto Podval, saiu ileso, pois foi agredido na porta do Fórum quando chegava para o julgamento. ${ }^{29}$

Observa-se assim, que muito embora a mídia exerça um papel importantíssimo no que se refere ao reforço do princípio da publicidade do processo penal, atuando, muitas vezes, a favor do Acusado e garantindo que não haja arbitrariedades no seu julgamento, em outros casos, a sua atuação mostra-se extremamente prejudicial, violando seus direitos e garantias, tais como a da presunção de inocência. ${ }^{30}$ Tal fato mostra-se ainda mais grave se levadas em conta as possibilidades de engano dos meios de comunicação, uma vez que elaboram matérias de caráter conclusivo em fases muito preliminares das investigações. Como se pode concluir a partir do exemplo do caso "Escola base" 31 , os graves danos propiciados pela divulgação de fatos inverídicos pela imprensa, ainda que indenizáveis, acarretam consequências muitas vezes irreversíveis, especialmente quando relacionados a casos criminais de grande repercussão.

No que se refere aos jurados, pelas razões já expostas acima, quais sejam, a sua não necessária formação jurídica, a falta de garantias orgânicas e o julgamento por íntima convicção, a exposição destes às eventuais matérias jornalísticas tende a afetá-los de maneira mais acentuada e a colocar em cheque de maneira mais grave, garantias como a de um devido processo legal, do juiz imparcial e da presunção de inocência. Conforme estudos elaborados por Moran e $\mathrm{Cutler}^{32}$, a exposição dos jurados à publicação de

\footnotetext{
${ }^{28}$ MORETZSOHN, Sylvia. Op. Cit. p. 518.

${ }^{29}$ FARAH, Tatiana. Caso Isabela: Advogado do casal Nardoni é agredido na entrada do Fórum. O Globo, 24/03/2010, atualizado em 01/11/2011. Disponível em: < http://oglobo.globo.com/brasil/caso-isabellaadvogado-do-casal-nardoni-agredido-na-entrada-do-forum-3035252 >. Acesso em 13 de janeiro de 2017.

30 Conforme explica Jorge de Figueiredo Dias, a ultrapassagem do limite ideal de publicidade de um determinado caso concreto oferece elevado risco para um "Fair Trial" do Acusado, uma vez que pode desencadear campanhas emocionais ou demagógicas em seu favor ou contra ele. Segundo o autor, em alguns casos, a simples comunicação de dados relativos à autoria e a culpabilidade de determinado caso pode violar os mais básicos princípios do processo penal, acabando por substituir o "legal trial by court" pelo "trial by newspaper”. DIAS, Jorge de Figueiredo. Direito processual penal. p. 226.

${ }^{31}$ Em março de 1994, foram feitas denúncias por pais de alunos de uma escola de São Paulo, de que donos e funcionários da mesma teriam praticado abuso sexual contra seus filhos. $\mathrm{O}$ delegado responsável pelo caso, com base em informações preliminares e sem verificar a veracidade das mesmas, divulgou os fatos à imprensa, o que levou a uma grande comoção popular, fazendo com que a escola fosse saqueada e depredada, os donos fossem a falência e recebessem diversas ameaças de morte através de telefonemas anônimos. Meses depois, o inquérito policial concluiu pela inocência dos acusados, uma vez que os alegados abusos jamais teriam ocorrido. AZEVEDO, Bernardo Montalvão de. O método fenomenológico proposto por Edmund Husserl e o caso escola base. p. 206-207.

32 MORAN; CUTLER apud BIDINO, Claudio. Mídia, crime e justiça criminal nos Estados Unidos: a ineficácia dos mecanismos judiciais disponíveis para impedir a perniciosa influência da imprensa sobre os jurados nos casos criminais de grande apelo popular. p. 233.
} 
Revista Eletrônica de Direito Processual - REDP.

Rio de Janeiro. Ano 13. Volume 20. Número 1. Janeiro a Abril de 2019

Periódico Quadrimestral da Pós-Graduação Stricto Sensu em Direito Processual da UERJ

Patrono: José Carlos Barbosa Moreira (in mem.). ISSN 1982-7636. pp. 513-531

www.redp.uerj.br

informações desfavoráveis ao réu reforça ou cria neles determinados preconceitos, aos quais não existem razões para crer que sejam eliminados antes do veredito final. ${ }^{33}$ Aliás, pelo contrário, conforme explica Claudio Bidino, estudos comprovam que a exposição a informações desfavoráveis ao réu divulgadas pela mídia influencia não apenas na preconcepções dos jurados, mas também, pode levar os mesmos a ter uma tendência maior a decidir de maneira contrária a aquele. ${ }^{34}$ Exemplo disto, são os estudos elaborados por Sue, Smith e Pedroza ${ }^{35}$; e Ruva, McEvoy e Bryant ${ }^{36}$.

\section{DO NECESSÁRIO PONTO DE CONCORDÂNCIA PRÁtiCA ENTRE A PRESUNÇÃO DE INOCÊNCIA E A LIBERDADE DE IMPRENSA}

Pelo exposto, no que tange ao instituto do Tribunal do Júri, observa-se um claro conflito de princípios, garantias e finalidades do processo penal. Isto porque, a liberdade de expressão através de atividades intelectuais, artísticas, científicas e de comunicação é prevista pelo artigo $5^{\circ}$., inciso IX, da Constituição Federal do Brasil, que garante ainda a sua isenção de censura ou licença." ${ }^{37}$ Desta forma, o indivíduo é livre para exteriorizar os juízos provenientes de sua consciência através de qualquer instrumento que o possibilite. ${ }^{38}$

Conforme explica Daniel Sarmento, a garantia da liberdade de expressão, assim como a liberdade de pensamento, fundamenta-se na necessária possibilidade de interação, entre os indivíduos, para a formação e desenvolvimento da personalidade, tutelando ainda,

\footnotetext{
33 Às mesmas conclusões chegaram Tans e Chaffee, após analisarem 150 pessoas instadas a descrever um homem acusado da prática de determinado crime, após terem sido expostas a diferentes tipos de publicidade. No mesmo sentido, Constantini e King entrevistaram 700 membros do rol de jurados de Yolo, na Califórnia, levando em conta ainda, seus status sociais e econômicos. Concluíram que todos estes fatores, principalmente a influência da ostensiva publicidade, influíram no julgamento dos entrevistos com relação a casos reais. Todos estes estudos foram elencados por Claudio Bidino, em: BIDINO, Claudio. Op. Cit. p. 232-233.

${ }^{34}$ Ibidem. p. 232.

${ }^{35} 158$ estudantes universitários foram recrutados para participar de um júri simulado, sendo que, parte deles foi exposta, previamente, a uma prova processualmente inadmissível e que sugeria fortemente a culpa do Acusado. Muito embora eles próprios afirmassem não ter sido influenciados, ao final do julgamento, $53 \%$ daqueles que tiveram contato com a prova votaram pela condenação, contra $23 \%$ dos que não tiveram contato com a mesma. SUE; SMITH; PEDROZA apud BIDINO, Claudio. Op. Cit. p. 234-235.

36 Os pesquisadores analisaram 558 estudantes, chegando à conclusão de que a exposição destes à informações prévias desfavoráveis ao réu, tais como antecedentes criminais e confissões retratadas em juízo, estão mais inclinados a condená-lo. RUVA; McEVOY; BRYANT apud BIDINO, Claudio. Mídia, crime e justiça criminal nos Estados Unidos: a ineficácia dos mecanismos judiciais disponíveis para impedir a perniciosa influência da imprensa sobre os jurados nos casos criminais de grande apelo popular. p. 236.

37 BRASIL. Constituição da República Federativa do Brasil de 1988. Disponível em: < http://www.planalto.gov.br/ccivil_03/constituicao/constituicaocompilado.htm >. Acesso em 11 de janeiro de 2017.

${ }^{38}$ MEDINA, José Miguel Garcia. Constituição Federal Comentada. p. 74.
} 
Revista Eletrônica de Direito Processual - REDP.

Rio de Janeiro. Ano 13. Volume 20. Número 1. Janeiro a Abril de 2019

Periódico Quadrimestral da Pós-Graduação Stricto Sensu em Direito Processual da UERJ

Patrono: José Carlos Barbosa Moreira (in mem.). ISSN 1982-7636. pp. 513-531

www.redp.uerj.br

uma verdadeira democracia participativa através de um amplo acesso a informações e opiniões sobre assuntos de interesse público, possibilitando a influência de seus concidadãos e a prevalência das melhores idéias. ${ }^{39}$

Em Portugal, a Constituição da República Portuguesa prevê em seu artigo 38 a liberdade de imprensa, tutelando ainda, em seu artigo 37, a liberdade de expressão, garantindo o direito de expressão e divulgação livre de pensamento por todos os meios possíveis, bem como o direito à informação sem impedimentos ou discriminações, sendo proibida, ainda, a censura. ${ }^{40}$

Importante destacar ainda, o princípio da publicidade dos atos judiciais, previsto, no Brasil pela Constituição Federal em seu artigo $5^{\circ}$., LX, que só permite sua restrição nos casos em que a defesa da intimidade ou o interesse social o exigirem, e pelo Artigo 93, inciso IX, que prevê que todos os julgamentos serão públicos, podendo, somente, serem restritos alguns atos às partes e/ou advogados nos casos em que não aja prejuízo do interesse público à informação. ${ }^{41}$

A Constituição da República Portuguesa tem previsão semelhante, garantindo audiências públicas, salvo decisão em contrário, devidamente fundamentada na garantia da dignidade das pessoas e da moral pública, bem como na salvaguarda do funcionamento do próprio tribunal. ${ }^{42}$ Desta forma, o público em geral tem garantido o direito à assistência de atos como a audiência de julgamento e à narração de atos processuais ou a sua reprodução por meios de comunicação social, salvo as limitações supracitadas. ${ }^{43}$

Conforme explica Jorge de Figueiredo Dias, porém, a publicidade do processo penal, caso utilizada de maneira excessiva pela grande imprensa, coloca em cheque, muitas vezes, o princípio da presunção de inocência, uma vez que acaba contribuindo indiretamente para um sistema de julgamento sem julgamento. ${ }^{44}$ Este princípio, previsto

\footnotetext{
39 CANOTILHO, J.J. Gomes; MENDES, Gilmar F.; SARLET, Ingo W.; STRECK, Lenio L. (Coords.). Comentários à Constituição do Brasil.. p. 255.

40 PORTUGAL. Constituição da República Portuguesa. Disponível em: < http://www.parlamento.pt/Legislacao/Paginas/ConstituicaoRepublicaPortuguesa.aspx >. Acesso em $16 \mathrm{de}$ janeiro de 2017.

41 BRASIL. Constituição da República Federativa do Brasil de 1988. Disponível em: < http://www.planalto.gov.br/ccivil_03/constituicao/constituicaocompilado.htm >. Acesso em 11 de janeiro de 2017.

42 PORTUGAL. Constituição da República Portuguesa. Disponível em: < http://www.parlamento.pt/Legislacao/Paginas/ConstituicaoRepublicaPortuguesa.aspx $>$. Acesso em $16 \mathrm{de}$ janeiro de 2017.

${ }^{43}$ ANTUNES, Maria João. Direito processual penal. p. 174.

${ }^{44}$ DIAS, Jorge de Figueiredo. Direito processual penal. p. 227.
} 
Revista Eletrônica de Direito Processual - REDP.

Rio de Janeiro. Ano 13. Volume 20. Número 1. Janeiro a Abril de 2019

Periódico Quadrimestral da Pós-Graduação Stricto Sensu em Direito Processual da UERJ

Patrono: José Carlos Barbosa Moreira (in mem.). ISSN 1982-7636. pp. 513-531

www.redp.uerj.br

pela Constituição Federal brasileira de 1988 , em seu artigo $5^{\circ}$., LVII ${ }^{45}$, e pela Constituição

da República Portuguesa no artigo 32, n. $2{ }^{46}$ se consubstancia, no processo penal, como verdadeiro ônus probatório da Acusação, devendo esta evidenciar de maneira suficiente a culpa do réu, pois, caso contrário, deve este permanecer em seu estado natural, que é o de inocência. ${ }^{47} \_48$

Assim sendo, problemática se mostra a definição de um ponto de concordância prática entre a publicidade dos atos judiciais e os direitos do Acusado a um julgamento imparcial e a não ser considerado culpado antes de sentença penal condenatória transitada em julgado, questão esta que se torna ainda mais significativa no âmbito dos julgamentos de competência do Tribunal do Júri, especialmente nos de grande repercussão midiática. Desta forma, a questão que se levanta é a de saber quais seriam os instrumentos idôneos a garantir ao Acusado um julgamento justo e imparcial, nos casos supracitados.

Em Portugal ${ }^{49}$, o Código de Processo Penal prevê, nos termos do artigo 86, a possibilidade de sujeição do processo, durante a fase do inquérito, a segredo de justiça, mediante requerimento do argüido, assistente ou ofendido, quando o juiz de instrução, após oitiva do Ministério Público, entender que a publicidade é prejudicial às partes. Nestes casos, o parquet também tem o poder de decidir pela aplicação do instituto, devendo, porém, sua decisão ser validada pelo juiz de instrução. ${ }^{50} 51$

\footnotetext{
45 "Ninguém será considerado culpado até o trânsito em julgado de sentença penal condenatória." BRASIL. Constituição da República Federativa do Brasil de 1988. Disponível em: < http://www.planalto.gov.br/ccivil_03/constituicao/constituicaocompilado.htm >. Acesso em 11 de janeiro de 2017.

46 "Todo arguido se presume inocente até o trânsito em julgado da sentença de condenação, devendo ser julgado no mais curto prazo compatível com as garantias de defesa." PORTUGAL. Constituição da República Portuguesa. Disponível em: http://www.parlamento.pt/Legislacao/Paginas/ConstituicaoRepublicaPortuguesa.aspx >. Acesso em 16 de janeiro de 2017.

${ }^{47}$ NUCCI, Guilherme de Souza. Manual de processo penal e execução penal. p. 33-34.

${ }^{48}$ Interessante observar que, segundo Maria João Antunes, no ordenamento jurídico português o princípio da presunção de inocência tem validade apenas para a matéria de fato, mas não para a de direito. Por sua vez, conforme explica Guilherme de Souza Nucci, o ordenamento jurídico brasileiro, através do princípio do "favor rei", garante que, quando dispositivos processuais penais tenham interpretações razoavelmente duvidosas, deve ser aplicada a versão mais favorável ao Acusado. ANTUNES, Maria João. Op. Cit. p. 172; NUCCI, Guilherme de Souza. Op. Cit. p. 34.

${ }^{49}$ Conforme assevera Paulo de Sousa Mendes, apesar da estranheza da regra geral da publicidade do inquérito policial, cujo sistema não encontra paralelos em outros ordenamentos conhecidos, acabou sendo incorporada pacificamente no cotidiano das investigações criminais. MENDES, Paulo de Sousa. Lições de direito processual penal. p. 67-68.

${ }^{50}$ Importante destacar que, nos termos do referido dispositivo, a publicidade assegurada pelo diploma não abrange dados relacionados à reserva da vida privada que não se refiram a meios de prova. PORTUGAL. Código de processo penal. Disponível em:
} 
Revista Eletrônica de Direito Processual - REDP.

Rio de Janeiro. Ano 13. Volume 20. Número 1. Janeiro a Abril de 2019

Periódico Quadrimestral da Pós-Graduação Stricto Sensu em Direito Processual da UERJ

Patrono: José Carlos Barbosa Moreira (in mem.). ISSN 1982-7636. pp. 513-531

www.redp.uerj.br

No Brasil, o artigo 201, § 6º do Código de Processo Penal, prevê a possibilidade de determinação, por parte do magistrado, de segredo de justiça relativo a dados, depoimentos e quaisquer outras informações constantes dos autos, com a finalidade de, dentre outras, evitar que a exposição aos meios de comunicação prejudique interesses relativos à vida privada, à honra, à intimidade e a imagem do ofendido. ${ }^{52}$ Observa-se assim, que muito embora parte da doutrina entenda que a preservação de direitos do réu também deva fundamentar a decretação do segredo de justiça, uma vez que a execração pública de qualquer participante não deveria ser regra no processo penal, a prática nos mostra que os poucos casos em que tal instituto é utilizado são, em sua grande maioria, para tutela do ofendido, especialmente em casos relacionados com crimes sexuais ou envolvendo menores. $^{53}$

Dispõe ainda, o ordenamento jurídico brasileiro, do instituto do "desaforamento", previsto pelo artigo 427 do Código de Processo Penal ${ }^{54}$, que prevê a possibilidade de mudança do foro competente, nos casos previstos em lei. Conforme explica Guilherme de Souza Nucci, especialmente no que se refere aos casos de suspeita de imparcialidade do júri, o referido instituto não ofenderia o princípio do juiz natural, uma vez que é medida excepcional, prevista em lei e que visa justamente garantir a imparcialidade no julgamento, já que não haveria possibilidade de justiça com um corpo de jurados tendenciosos. ${ }^{55}$

http://www.pgdlisboa.pt/leis/lei_mostra articulado.php?nid=199\&tabela=leis $>$. Acesso em 10 de janeiro de 2017.

${ }^{51}$ Vale salientar a diferença existente entre os ordenamentos jurídicos brasileiro e português, no que se refere aos limites de publicidade estabelecidos aos meios de comunicação social, uma vez que, enquanto este último proíbe, no artigo 88 do Código de Processo Penal, a transmissão ou registro de imagens, ou tomadas de som de atos processuais, especialmente da audiência, no Brasil, nos casos de maior repercussão, é muito comum chamadas ao vivo para a transmissão dos mesmos. No supracitado caso Isabella Nardoni, a grade de programas fora, inclusive, alterada em diversos canais, para que a sentença fosse lida ao vivo. Não bastasse isso, a chamada "TV Justiça" transmite ao vivo os julgamentos do Supremo Tribunal Federal, inclusive os criminais, como foi o caso do "Mensalão". PORTUGAL. Código de processo penal. Disponível em: < http://www.pgdlisboa.pt/leis/lei_mostra_articulado.php?nid=199\&tabela=leis >. Acesso em 10 de janeiro de 2017.

${ }^{52}$ BRASIL. Decreto-Lei no . 3.689, de 3 de outubro de 1941: Código de Processo Penal. Disponível em: < http://www.planalto.gov.br/ccivil_03/decreto-lei/Del3689.htm >. Acesso em 11 de janeiro de 2017.

${ }_{53}^{53}$ NCCI, Guilherme de Souza. Código de processo penal comentado. p. 540.

54 “Art. 427. Se o interesse da ordem pública o reclamar ou houver dúvida sobre a imparcialidade do júri ou a segurança pessoal do acusado, o Tribunal, a requerimento do Ministério Público, do assistente, do querelante ou do acusado ou mediante representação do juiz competente, poderá determinar o desaforamento do julgamento para outra comarca da mesma região, onde não existam aqueles motivos, preferindo-se as mais próximas." BRASIL. Decreto-Lei n ${ }^{o}$. 3.689, de 3 de outubro de 1941: Código de Processo Penal. Disponível em: < http://www.planalto.gov.br/ccivil_03/decreto-lei/Del3689.htm >. Acesso em 11 de janeiro de 2017.

${ }^{55}$ NUCCI, Guilherme de Souza. Tribunal do júri. p. 107. 
Revista Eletrônica de Direito Processual - REDP.

Rio de Janeiro. Ano 13. Volume 20. Número 1. Janeiro a Abril de 2019

Periódico Quadrimestral da Pós-Graduação Stricto Sensu em Direito Processual da UERJ

Patrono: José Carlos Barbosa Moreira (in mem.). ISSN 1982-7636. pp. 513-531

www.redp.uerj.br

Observa-se, porém, que se trata de medida processual de rara acolhida, uma vez que a imparcialidade dos jurados é de difícil comprovação judicial. ${ }^{56}$

Tal jurisprudência, no nosso entendimento, deve deixar de ser acolhida, uma vez que cada vez mais os meios de comunicação social exercem influência na formação da opinião do grande público, sendo que, muitas vezes, através de programas que sensacionalizam fatos criminosos, aqueles nem sempre são comprometidos com os direitos e garantias constitucionais, acabando por exercer verdadeiro julgamento antecipado e público do Acusado. ${ }^{57}$

Desta forma, o instituto do desaforamento, apesar de medida excepcional, deveria ser efetivamente aplicado quando existissem sólidas evidências de imparcialidade dos jurados responsáveis pelo caso, uma vez que estes, amparados pelo sistema da íntima convicção, levariam em conta, muitas vezes, informações transmitidas fora do contraditório e em descompromisso com a verdade. ${ }^{58}$

Importante destacar, porém, que apesar de se mostrar um instrumento apto a impedir um julgamento imparcial em cidades pequenas, nas quais a gravidade do crime ou a qualidade da vítima ou do agressor tenha levado a uma comoção pública generalizada, o mesmo não pode se dizer com relação a casos nacionalmente notórios ou ocorridos em grandes comarcas, uma vez que seria inócua a sua transferência. ${ }^{59}$

Para estas situações, Guilherme de Souza Nucci defende uma mudança de atitude dos próprios meios de comunicação social, alertando que para compatibilizar a liberdade de transmissão de informações com o direito à intimidade das partes e a um julgamento justo, a imprensa deveria abster-se de adentrar na vida pessoal dos participantes processuais, especialmente do réu, além de evitar tecer opiniões relacionadas ao caso, mantendo-se, única e exclusivamente, na área da notícia de fatos. ${ }^{60}$

Paulo Rangel, por sua vez, entende que o instituto do Tribunal do Júri no ordenamento jurídico brasileiro deve ser readequado para se adaptar aos mandamentos da Constituição Federal de 1988, sendo que, as normas que os contrariarem estarão

\footnotetext{
${ }^{56}$ Conforme exemplifica Aury Lopes Jr., se a prova da suspeição por quebra da imparcialidade de um juiz togado singular já de difícil acolhida, o que dizer sobre a comprovação de uma alegação genérica de imparcialidade de um corpo difuso de jurados. LOPES JR., Aury. Direito processual penal. p. 803.

${ }^{57}$ BATISTA, Nilo. Mídia e sistema penal no capitalismo tardio. p. 261.

${ }^{58}$ SILVA, Diana Demarchi. Tribunal do júri: a influência da mídia na (im)parcialidade do conselho de sentença. p. 59.

${ }^{59}$ NUCCI, Guilherme de Souza. Tribunal do júri. p. 109.

${ }^{60}$ NUCCI, Guilherme de Souza. Código de processo penal comentado. p. 535.
} 
Revista Eletrônica de Direito Processual - REDP.

Rio de Janeiro. Ano 13. Volume 20. Número 1. Janeiro a Abril de 2019

Periódico Quadrimestral da Pós-Graduação Stricto Sensu em Direito Processual da UERJ

Patrono: José Carlos Barbosa Moreira (in mem.). ISSN 1982-7636. pp. 513-531

www.redp.uerj.br

revogadas. Neste sentido, apesar de prever o sigilo das votações, em seu artigo $5^{\circ}$., XXXVIII, "b", a Carta Magna brasileira prevê, em seu artigo 93, IX, que todos os julgamentos do Poder Judiciário serão públicos e que serão fundamentadas todas as decisões, sob pena de nulidade. Desta forma, defende o fim do sistema da íntima convicção, mesmo no âmbito do Tribunal do Júri. ${ }^{61}$

Tratando do que considera ser o "calcanhar de Aquiles" do sistema do tribunal popular, Lenio Streck entende não ser compatível com um garantista Estado Democrático de Direito um modelo no qual não haja a devida fundamentação ou motivação das decisões, tal como o da íntima convicção. Assevera, porém, que se trata de problema de difícil resolução, uma vez que a própria Constituição Federal do Brasil assegura o sigilo das votações. Por outro lado, entende que uma Emenda Constitucional que altere o funcionamento do júri não violaria cláusulas pétreas, uma vez que a chamada "sala secreta" e, consequentemente, o sigilo das votações, seriam mantidos, não se tratando, por assim ser, de modificação que acabasse por abolir garantias. ${ }^{62}$

No mesmo sentido é o entendimento de Aury Lopes Jr., que apesar de considerar o Tribunal do Júri prescindível para a administração da justiça, sustenta a inviabilidade de sua pura e simples extinção, diante da previsão constitucional do instituto. Defende, porém, que sejam feitas nele profundas e estruturais modificações, a fim de ser compatível com um processo penal efetivamente garantista. ${ }^{63}$

Analisando os instrumentos dos quais dispõe o ordenamento jurídico norteamericano, que podem ser divididos entre aqueles que visam impedir a seleção de jurados imparciais, os que intendem neutralizar eventuais influências recebidas pelos já selecionados, os que pretendem blindá-los de receber novas informações transmitidas pelos meios de comunicação e os que tem como objetivo restringir a própria veiculação de determinados conteúdos pela imprensa, Claudio Bidino defende ser esta última opção a mais eficaz na proteção dos jurados contra indevidas influencias midiáticas, apesar de ressaltar a pouca aplicação prática desta medida. Segundo o autor, faz-se necessária uma

\footnotetext{
${ }^{61}$ RANGEL, Paulo. Direito processual penal. p. 554.

${ }^{62}$ STRECK, Lenio Luiz. Tribunal do júri: símbolos e rituais. p. 173-174.

${ }^{63}$ LOPES JR., Aury. Direito processual penal. p. 827.
} 
Revista Eletrônica de Direito Processual - REDP.

Rio de Janeiro. Ano 13. Volume 20. Número 1. Janeiro a Abril de 2019

Periódico Quadrimestral da Pós-Graduação Stricto Sensu em Direito Processual da UERJ

Patrono: José Carlos Barbosa Moreira (in mem.). ISSN 1982-7636. pp. 513-531

www.redp.uerj.br

maior regulação do setor, passando a ser proibida a veiculação de determinadas informações, especialmente nas fases embrionárias das investigações e processos. ${ }^{64}$

Conforme exposto, com a devida vênia aos entendimentos em contrário, nos casos em que a repercussão midiática tenha se mostrado apenas regional, entendemos que o instituto do desaforamento ainda é o principal instrumento para garantir a imparcialidade dos jurados, devendo, assim, passar a ser aplicado de maneira mais significativa, ainda que excepcional, pelos tribunais brasileiros, quando houver fortes indícios de que a repercussão do caso influenciará o julgamento.

Por sua vez, nos casos em que a exposição midiática se dera de maneira relevante em todo o território nacional, o instituto em comento acabaria por se mostrar inócuo, não devendo, portanto, ser aplicado. Não entendemos, porém, pelos riscos que lhe são inerentes e pela excessiva restrição de garantias que implica, que a regulamentação da imprensa seja o melhor caminho, apesar de entender que seja, sim, favorável e necessária uma mudança de mentalidade de seus membros.

Desta forma, de lege ferenda, acreditamos que, de fato, no atual estágio alcançado pelo direito processual penal, para que seja efetivamente garantista e compatível com um Estado Democrático de Direito, não pode haver um sistema no qual se admita decisões não motivadas ou expressamente fundamentadas, tal qual o da íntima convicção adotado pelo Tribunal do Júri. Assim sendo, no caso específico do ordenamento jurídico brasileiro, dentre as concretas e basilares mudanças das quais padecem o instituto em comento, mister se faz uma alteração no sistema decisório, de forma com que possam ser compatibilizados os mandamentos constitucionais do sigilo das votações e da necessária fundamentação das decisões.

\section{CONCLUSÃO:}

Nos termos expostos, observa-se que o Tribunal do Júri se mostrou, ao longo da história, um instrumento de importante resistência frente aos abusos característicos dos governos autoritários do século XVIII, tendo sido difundido como um forte exemplo de instituição democrática e coerente com o Estado de Direito.

\footnotetext{
${ }^{64}$ BIDINO, Claudio. Mídia, crime e justiça criminal nos Estados Unidos: a ineficácia dos mecanismos judiciais disponíveis para impedir a perniciosa influência da imprensa sobre os jurados nos casos criminais de grande apelo popular. p. 240-254.
} 
Revista Eletrônica de Direito Processual - REDP.

Rio de Janeiro. Ano 13. Volume 20. Número 1. Janeiro a Abril de 2019

Periódico Quadrimestral da Pós-Graduação Stricto Sensu em Direito Processual da UERJ

Patrono: José Carlos Barbosa Moreira (in mem.). ISSN 1982-7636. pp. 513-531

www.redp.uerj.br

Ocorre que, ao longo dos anos, novas questões relativas ao funcionamento do instituto foram levantadas, fazendo com que não apenas os métodos, como até mesmo a sua imperiosidade passassem a ser questionadas por parte da doutrina. Interessante observar, que ao contrário de tempos passados, os argumentos utilizados pelos refratores do tribunal popular não são de caráter autoritário, mas, pelo contrário, são cada vez mais numerosas as opiniões que, visando resguardar garantias do Acusado, defendem mudanças substanciais no mesmo ou até mesmo a sua extinção.

Conforme discutido, o principal problema identificado no Tribunal do Júri, especialmente no ordenamento jurídico brasileiro, diz respeito ao modelo decisório dos jurados, que baseados no sistema da "íntima convicção", não fundamentam nem motivam seus vereditos. Tal questão vê-se ainda mais problemática tendo-se em vista a cada vez mais presente influência dos meios de comunicação social nos casos criminais e a falta de garantias orgânicas e formação jurídica dos juízes leigos, que se vêem mais indefesos e vulneráveis frente a pressões externas. Além disso, dependendo do grau de repercussão do caso, os mesmos já chegam à fase de julgamento contaminados por inúmeras "evidências" coletadas pela imprensa, sendo que estas muitas vezes seriam processualmente inadmissíveis e elaboradas em descompromisso com a verdade.

Assim sendo, a fim de garantir a imparcialidade dos jurados e, consequentemente, o direito do Acusado a um julgamento justo, o ordenamento jurídico brasileiro prevê o instituto do "desaforamento", que se mostra como um instrumento idôneo para os casos nos quais, apesar de ter alcançado grande repercussão e comoção popular, esta não ultrapassou os limites de uma pequena região ou comarca, possibilitando, assim, a sua transferência para outro foro no qual o caso seja ainda relativamente desconhecido.

Nas demais situações, porém, o referido instituto não é efetivo, uma vez que a ampla divulgação nacional impossibilitaria a sua transferência para algum local no qual os jurados não tivessem já, uma ideia preconcebida do caso. Assim sendo, e tendo-se em vista a inaptidão e inadequação dos demais instrumentos dos quais dispõe o ordenamento jurídico, mister se faz, dentre outras imperiosas modificações estruturais no funcionamento do tribunal popular, uma alteração no seu sistema decisório, de maneira com que, apesar de garantir o sigilo das votações, o veredito final seja fundamentado, possibilitando a eventual análise da correlação entre a decisão e as provas produzidas no processo, impedindo, assim, decisões corroboradas apenas por preconceitos pessoais e ideias produzidas e 
Revista Eletrônica de Direito Processual - REDP.

Rio de Janeiro. Ano 13. Volume 20. Número 1. Janeiro a Abril de 2019

Periódico Quadrimestral da Pós-Graduação Stricto Sensu em Direito Processual da UERJ

Patrono: José Carlos Barbosa Moreira (in mem.). ISSN 1982-7636. pp. 513-531

www.redp.uerj.br

reforçadas pela imprensa, readequando, assim, o Tribunal do Júri a uma ciência processual penal garantista inerente a um Estado Democrático de Direito.

\section{REFERÊNCIAS BIBLIOGRÁFICAS}

AlBuQUerQue, Paulo Sérgio Pinto de. Comentário do Código de Processo Penal: à luz da Constituição da República e da Convenção Européia dos Direitos do Homem. 3.ed. Lisboa: Universidade Católica Editora, 2009.

ANTUNES, Maria João. Direito processual penal. Coimbra: Almedina, 2016.

ARAÚJO, Marcelo Cunha de. A volta do discurso dos suplícios em um país ávido por vingança: os casos João Hélio e Isabella Nardoni. De Jure: Revista Jurídica do Ministério Público do Estado de Minas Gerais, Belo Horizonte, n.10, p. 190-201., jan./jun. 2008.

AZEVEDO, Bernardo Montalvão de. O método fenomenológico proposto por Edmund Husserl e o caso escola base. Direito Público, São Paulo, v. 8, n. 35, p. 205-222, set./out. 2010.

BATISTA, Nilo. Mídia e sistema penal no capitalismo tardio. Revista Brasileira de Ciências Criminais, São Paulo, v. 11, 42 Esp., p. 242-263, jan./mar. 2003.

BECHARA, Ana Elisa Liberatore Silva. "Caso Isabella": violência, mídia e direito penal de emergência. Boletim IBCCRIM, São Paulo, v. 16, n. 186, p. 16-17., mai. 2008.

BIDINO, Claudio. Mídia, crime e justiça criminal nos Estados Unidos: a ineficácia dos mecanismos judiciais disponíveis para impedir a perniciosa influência da imprensa sobre os jurados nos casos criminais de grande apelo popular. Revista Brasileira de Ciênciais Criminais, São Paulo, v. 22, n. 110, p. 227-257, set./out. 2014.

BRASIL. Decreto-Lei $n^{o}$. 3.689, de 3 de outubro de 1941: Código de Processo Penal. Disponível em: < http://www.planalto.gov.br/ccivil_03/decreto-lei/Del3689.htm >. Acesso em 11 de janeiro de 2017.

BRASIL. Constituição da República Federativa do Brasil de 1988. Disponível em: < http://www.planalto.gov.br/ccivil_03/constituicao/constituicaocompilado.htm >. Acesso em 11 de janeiro de 2017. 
Revista Eletrônica de Direito Processual - REDP.

Rio de Janeiro. Ano 13. Volume 20. Número 1. Janeiro a Abril de 2019

Periódico Quadrimestral da Pós-Graduação Stricto Sensu em Direito Processual da UERJ

Patrono: José Carlos Barbosa Moreira (in mem.). ISSN 1982-7636. pp. 513-531

www.redp.uerj.br

CANOTILHO, J.J. Gomes; MENDES, Gilmar F.; SARLET, Ingo W.; STRECK, Lenio L.

(Coords.). Comentários à Constituição do Brasil. São Paulo: Saraiva/Almedina, 2013.

DEZEM, Guilherme Madeira. Curso de processo penal. São Paulo: Editora Revista dos Tribunais, 2015.

DIAS, Jorge de Figueiredo. Direito processual penal. 1'. Vol. Coimbra: Coimbra Editora, 1974.

FARAH, Tatiana. Caso Isabela: Advogado do casal Nardoni é agredido na entrada do Fórum. $O$ Globo, 24/03/2010, atualizado em 01/11/2011. Disponível em: < http://oglobo.globo.com/brasil/caso-isabella-advogado-do-casal-nardoni-agredido-

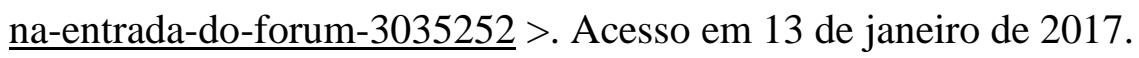

FAUSTO, Boris. História do Brasil. 2.ed. São Paulo: Editora da Universidade de São Paulo, 1995.

GOMES, Luiz Flávio. Campanha da Sheherazade: adote um bandido! Boletim IBCCRIM, São Paulo, v.22, n.256, p.2-3, mar. 2014.

JÓLLUSKIN, Glória. O tribunal do júri no ordenamento jurídico português: uma abordagem na perspectiva da psicologia. Revista da Faculdade de Ciências Humanas e Sociais. Porto: Edições Universidade Fernando Pessoa, 2009, p. 116-126.

LOPES JR., Aury. Direito processual penal. 10.ed. São Paulo: Saraiva, 2013.

MACHADO, Antônio Alberto. Curso de processo penal. 4.ed. São Paulo: Atlas, 2012.

MEDINA, José Miguel Garcia. Constituição Federal Comentada. 3.ed. São Paulo: Revista dos Tribunais, 2014.

MENDES, Paulo de Sousa. Lições de direito processual penal. Coimbra: Almedina, 2013.

MIRANDA, Jorge; MEDEIROS, Rui. Constituição portuguesa anotada - Tomo III: organização do poder político, garantia e revisão da constituição, disposições finais

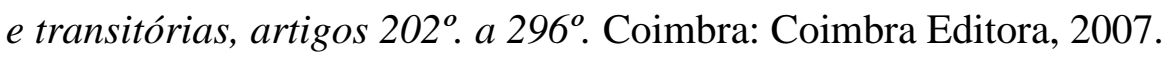

MORETZSOHN, Sylvia. “O crime que chocou o Brasil”: mídia, justiça e opinião pública na primeira fase do caso Isabella Nardoni. Discursos Sediciosos: crime, direito e sociedade, Rio de Janeiro, 17/18, p. 509-520., anual. 2010.

NUCCI, Guilherme de Souza. Código de processo penal comentado. 16. ed. rev., atual. e ampl. Rio de Janeiro: Forense, 2017. 
Revista Eletrônica de Direito Processual - REDP.

Rio de Janeiro. Ano 13. Volume 20. Número 1. Janeiro a Abril de 2019

Periódico Quadrimestral da Pós-Graduação Stricto Sensu em Direito Processual da UERJ

Patrono: José Carlos Barbosa Moreira (in mem.). ISSN 1982-7636. pp. 513-531

www.redp.uerj.br

NUCCI, Guilherme de Souza. Manual de processo penal e execução penal. 11.ed.rev. e atual. Rio de Janeiro: Forense, 2014.

NUCCI, Guilherme de Souza. Tribunal do júri. São Paulo: Editora Revista dos Tribunais, 2008.

OLIVEIRA, Eugênio Pacelli de. Curso de processo penal. 18. ed. rev. e ampl. atual. de acordo com as Leis n. 12.830, 12.850 e 12.878, todas de 2013. São Paulo: Atlas, 2014

PORTUGAL. Código de processo penal. Disponível em: < http://www.pgdlisboa.pt/leis/lei_mostra_articulado.php?nid=199\&tabela=leis $\quad>$. Acesso em 10 de janeiro de 2017.

PORTUGAL. Constituição da República Portuguesa. Disponível em:

〈http://www.parlamento.pt/Legislacao/Paginas/ConstituicaoRepublicaPortuguesa.aspx $>$.

Acesso em 10 de janeiro de 2017.

RANGEL, Paulo. Direito processual penal. 15.ed. rev., ampl. e atual. Rio de Janeiro: Editora Lumen Juris, 2008.

ROSA, Alexandre Morais da. Decisão no processo penal como bricolage de insignificantes. 2004. 429 f. Tese (Doutorado) - Curso de Direito, Universidade Federal do Paraná, Curitiba, 2004. Disponível em: <http://acervodigital.ufpr.br/handle/1884/1203 >. Acesso em 18 de janeiro de 2017.

SILVA, Diana Demarchi. Tribunal do júri: a influência da mídia na (im)parcialidade do conselho de sentença. 2015. 81 f. Monografia - (Bacharel em Direito) Universidade Federal de Santa Catarina, Florianópolis, 2015.

STRECK, Lenio Luiz. Tribunal do júri: símbolos e rituais. 4.ed.rev. e mod. Porto Alegre: Livraria do Advogado, 2001.

VIEIRA, Ana Lúcia Menezes. Processo penal e mídia. São Paulo: Editora Revista dos Tribunais, 2003. 